\title{
Efficiency of Entomopathogenic Fungi to Sugarcane White Leafhopper, Matsumuratettix hiroglyphicus (Matsumura) (Hemiptera: Cicadellidae)
} \author{
Uraichuen $^{1,2}$ \\ ${ }^{1}$ Department of Entomology, Kasetsart University, Thailand \\ ${ }^{2}$ National Biological Control Research Center, Kasetsart University, Thailand \\ ${ }^{3}$ Center of Excellence for Sugarcane, Kasetsart University, Thailand \\ ${ }^{4}$ Department of Entomology and Plant Pathology, Chiang Mai University, Thailand
}

Nichanun Kernasa ${ }^{1,2,3 *}$, Parichat Jamrutsri ${ }^{2}$, Siriya Kumpiro ${ }^{1,4}$, Roongnapa Korpaditskul ${ }^{3}$ and Sopon

Submission: March 02, 2018; Published: March 28, 2018

"Corresponding author: Nichanun Kernasa, Department of Entomology, Faculty of Agriculture Kamphaengsaen, Kasetsart University, Kamphaeng Saen campus, Nakhon Pathom, 73140, Thailand, Email: agropk@ku.ac.th

\begin{abstract}
Sugarcane White Leafhopper, Matsumuratettix hiroglyphicus (Matsumura) (Hemiptera: Cicadellidae) is an economic important insect pest of sugarcane in Thailand. The three entomopathogenic fungi, Metarhizium anisopliae isolated from the sugarcane longhorn beetle, Beauvaria brassiana isolated from the brown plant hopper and Purpureocillium lilacium (Paecilomyces lilacinus) isolated from M. hiroglyphicus were tested as biological control agents of $M$. hiroglyphicus. The results indicated that $M$. anisopliae isolated from $D$. buqueti showed the best pathocinity to $M$. hiroglyphicus adults with $\mathrm{LC}_{50} 7.39 \times 10^{6}$
\end{abstract}

\section{Introduction}

Sugarcane White Leafhopper, Matsumuratettix hiroglyphicus (Matsumura) (Hemiptera: Cicadellidae) is an economic important insect pest of sugarcane in Thailand. It represents as the reservoir of phytoplasma that cause sugarcane white leaf disease [1]. In recently, sugarcane white leaf disease spread out from the Northeastern region to the lower north region and the central region of Thailand. These causes sharply decrease in sugarcane yields. So that, entomopathogenic fungi become the discriminatory technique to control M. hiroglyphicus. This paper aims to evaluate the efficiency of three species of entomopathogenic fungi to $M$. hiroglyphicus adults in the laboratory.

\section{Materials and Methods}

\section{Insect culture}

The adults of $M$. hiroglyphicus were collect lively by setting the light trap in sugarcane field that having the white leaf disease at Bueng Samakkhi district, Kamphaeng Phet province. Then, transferred them to the National Biological Control Research Center, Central Regional Center, Kasetsart University, Kamphaeng Saen campus, Nakhon Pathom's laboratory for rearing. They were reared on the one month sugarcane that placed in the rounded plastic cages until we prompted to do the experiment and bioassay.

Study on pathogenicity of three species of entomopathogenic fungi to $M$. hiroglyphicus adults

The experiment consisted of three species of entomopathogenic fungi that were Metarhizium anisopliae isolated from the sugarcane longhorn beetle, Beauvaria brassiana isolated from the brown plant hopper and Purpureocillium lilacium (Paecilomyces lilacinus) isolated from M. hiroglyphicus compared with control, distill water mixed with $0.05 \%$ Triton X 100. Each treatment consisted of five replications that were five adults per one Petri-dish. The trial done by dropping $1 \mu \mathrm{l}$ of $10^{8}$ conidia/ml of each fungus on each adult. They were placed in $25 \pm 2{ }^{\circ} \mathrm{C}$ and $70 \pm 2 \% \mathrm{RH}$. The data were checked for ten days, the adults were checked that the spores of each fungus grow cover their bodies by the necked eyes. The data were collected and calculated by statistic tool.

\section{Bioassay of M. anisopliae to $M$. hiroglyphicus adults}

Metarhizium anisopliae was the better candidate of entomopathogenic fungus for controlling M. hiroglyphicus adults. We used five concentrations of M. anisopliae; $10^{5}, 10^{6} ; 10^{7} ; 10^{8}$ and 
$10^{9}$ conidia/ml compared with distill water mixed with $0.05 \%$ Triton X 100. Each treatment consisted of five replications that were five adults per one Petri-dish. The trial done by dropping $1 \mu \mathrm{l}$ of each concentration of each fungus on individual adult. They were placed in $25 \pm 2{ }^{\circ} \mathrm{C}$ and $70 \pm 2 \% \mathrm{RH}$. The data were checked for ten days, the adults were checked that the spores of each fungus grow cover their bodies by the necked eyes. The data were collected and calculated $\mathrm{LC}_{50}$ by probit analysis.

\section{Results and Discussion}

\section{Pathogenicity of three species of entomopathogenic} fungi to M. hiroglyphicus adults

Table 1: Percent mortality (\%) and $\mathrm{LT}_{50}$ (days) of $M$. hiroglyphicus adults caused by $M$. anisopliae, B. brassiana and $P$. lilacinum.

\begin{tabular}{|c|c|c|}
\hline Treatment & Percent Mortality (\%) & LT50 (days) \\
\hline Beauveria bassiana & $76.00 \mathrm{~b}$ & 8.5 \\
\hline $\begin{array}{c}\text { Metarhizium } \\
\text { anisopilae }\end{array}$ & $100.00 \mathrm{a}$ & 3.71 \\
\hline P. lilacinum & $68.00 \mathrm{~b}$ & 9.24 \\
\hline Control & $0.00 \mathrm{c}$ & - \\
\hline
\end{tabular}

Percent mortality within a column followed by the same letter are not significantly different based on DMRT ( $\leq \leq 0.05)$.

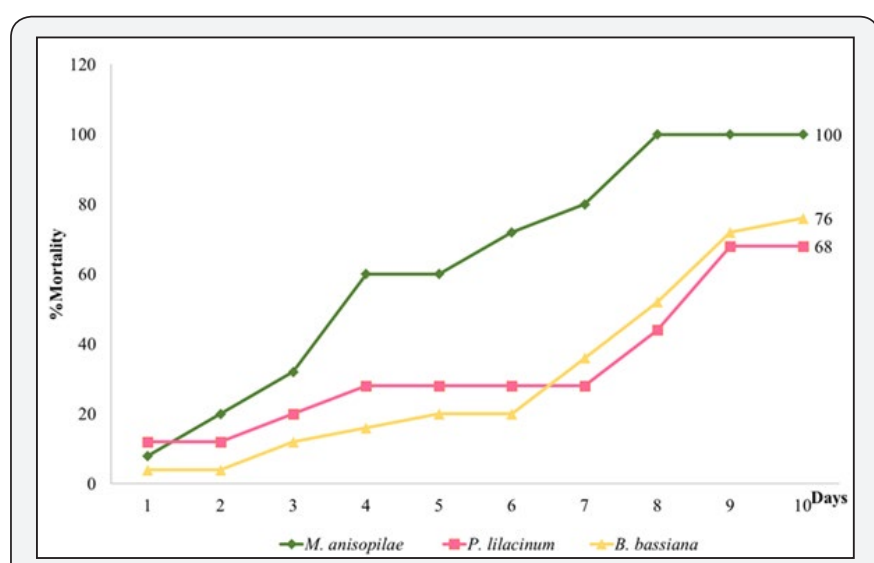

Figure 1: Percent mortality (\%) of $M$. hiroglyphicus adults caused by $M$. anisopliae, B. brassiana, $P$. lilacinum within ten days.

The results of pathogenicity of the three fungi revealed that they can infect M. hiroglyphicus adults. Percent mortalities of M. hiroglyphicus adults were significantly different between the three fungi there were 100, 76, 68 and 0 percent by $M$. anisopliae, B. brassiana, P. lilacinum and control, respectively. The $\mathrm{LT}_{50}$ indicated that $M$. anisopliae showed the rapid mortality was 3.71 days followed by B. brassiana, P. lilacinum that were 8.50 and 9.24 days, respectively (Table 1) and (Figure 1). Vestergaard et al. [2] treated M. anisopliae to adult Frankliniella occidentalis with resulted in at least $94 \%$ mortality at 7 days postinoculation. Annamalai et al. (2016) reported that B. brassiana showed percent mortality of $78.48 \%$ for the concentrations of $1.23 \times 108$ spores/mL to Thrips tabaci. Jone et al. [3] reported that
M. anisopliae strains were more virulent, with lower $\mathrm{LT}_{50}$ values, than were the B. bassiana strains [4].

\section{Bioassay of M. anisopliae to M. hiroglyphicus adults}

The result from pathogenicity indicated that $M$. anisopliae showed the highest percent mortality and lowest $\mathrm{LT}_{50}$ so that, we chosen M. anisopliae to do the bioassay to M. hiroglyphicus adults. The bioassay consisted of five treatments compared with control. The treatments were conidial suspensions $1 \times 10^{5}, 1 \times 10^{6}$, $1 \times 10^{7}, 1 \times 10^{8}, 1 \times 10^{9}$ conidia/ml and control. The results revealed that $M$. anisopliae showed $7.39 \times 10^{6}$ of the $\mathrm{LT}_{50}$ (Table 2). The probit analysis showed that $\mathrm{R}^{2}$ was 0.9638 (Figure 2).

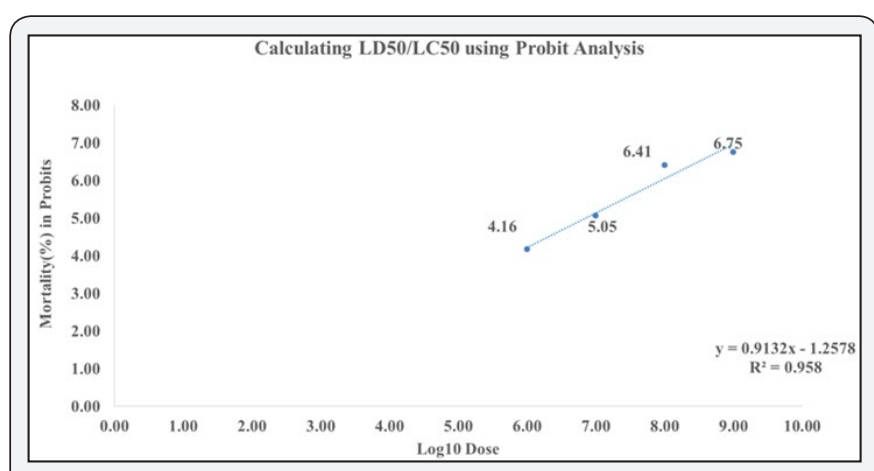

Figure 2: Probit analysis of five conidial suspensions of $M$. anisopliae to M. hiroglyphicus adults.

Table 2: $\mathrm{LT}_{50}$ of $M$. anisopliae to $M$. hiroglyphicus adults.

\begin{tabular}{|c|c|c|c|}
\hline $\begin{array}{c}\text { Conidia } \\
\text { Suspensions }\end{array}$ & LC $_{50}$ & 95\%Fiducial CI & \\
\cline { 1 - 1 } (Conidia/ml) & $\begin{array}{c}\text { (Conidia/ } \\
\text { ml) }\end{array}$ & Lower & Upper \\
\cline { 1 - 1 } $1 \times 105$ & \multirow{2}{*}{$7.39 \times 106$} & $2.29 \times 106$ & \multirow{2}{*}{$2.38 \times 107$} \\
\cline { 1 - 1 } $1 \times 106$ & & & \\
\cline { 1 - 1 } $1 \times 107$ & & & \\
\cline { 1 - 2 } $1 \times 108$ & & & \\
\cline { 1 - 2 } Control & & & \\
\hline
\end{tabular}

According to the results revealed that M. anisopliae isolated from $D$. buqueti showed the best pathocinity to M. hiroglyphicus adults with $\mathrm{LT}_{50} 7.39 \times 10^{6}$. This fungus will be a promising biological control agent to control M. hiroglyphicus in sugarcane plantations.

\section{References}

1. Hanboonsong Y, Choosai C, Panyim S, Damak S (2002) Transovarial transmission of sugarcane white leaf phytoplasma in the insect vetor Matsumuratettix hiroglyphicus (Matsumura). Insect Mol Biol 11(1): 97103.

2. Vestergaard S, Gillespie AT, Butt TM, Schreiter G, Eilenberg J (1995) Pathogenicity of the Hyphomycete Fungi Verticillium lecanii and Metarhizium anisopliae to the Western Flower Thrips, Frankliniella occidentalis. Biocontrol Science and Technology 5(2): 185-192. 
3. Jones WE, Grace JK, Tamashiro M (1996) Virulence of Seven Isolates of Beauveria bassiana and Metarhizium anisopliae to Coptotermes formosanus (Isoptera: Rhinotermitidae). Environmental Entomology 25(2): 481-487.
4. Annamalai M, Kaushik HD, Selvaraj K (2016) Bioefficacy of Beauveria bassiana (Balsamo) Vuillemin and Lecanicillium lecanii Zimmerman against Thrips tabaci Lindeman. Proceedings of the National Academy of Sciences, India Section B: Biological Sciences 86(2): 505-511.

\section{Your next submission with Juniper Publishers will reach you the below assets}

- Quality Editorial service

- Swift Peer Review

- Reprints availability

- E-prints Service

- Manuscript Podcast for convenient understanding

- Global attainment for your research

- Manuscript accessibility in different formats ( Pdf, E-pub, Full Text, Audio)

- Unceasing customer service

Track the below URL for one-step submission https://juniperpublishers.com/online-submission.php 